\title{
Methane production in in vitro studies as an effect of different additives to grass-clover silage
}

\author{
A. Cieślak ${ }^{1,4}$, A. Potkański ${ }^{1}$, J. Kowalczyk ${ }^{3}$, M. Szumacher-Strabel ${ }^{1}$, \\ K. Czaczyk ${ }^{2}$, A. Gubała ${ }^{1}$, M. Janicki ${ }^{1}$ and E. Szymankiewicz ${ }^{1}$
}

\author{
The August Cieszkowski Agricultural University of Poznań, \\ ${ }^{1}$ Department of Animal Nutrition and Feed Management \\ Wotyńska 33, 60-637 Poznań, Poland \\ ${ }^{2}$ Department of Biotechnology and Food Microbiology \\ Wojska Polskiego 48, 60-237 Poznań, Poland
}

${ }^{3}$ The Kielanowski Institute of Animal Physiology and Nutrition, Polish Academy of Sciences 05-110 Jabłonna, Poland

\begin{abstract}
The effects of biological (VTT) and chemical (KemiSile 2000) additives to grass-clover silage on methane emission, basic rumen fermentation pattern, rumen bacteria and protozoa were investigated using a batch culture system. Supplementing grass-clover silage with either additive significantly increased $(\mathrm{P} \leq 0.05)$ in vitro dry matter disappearance (IVDMD) and bacteria count. Overall, neither of the additives affected the VFA proportion. The only significant differences $(\mathrm{P} \leq 0.05)$ were in the isovalerate percentage and acetate:propionate ratio (A/P). Increased A/P and IVDMD levels, bacteria count and methane emission were found in both groups.
\end{abstract}

KEY WORDS: forage quality, methane production, rumen parameters, methane, in vitro

\section{INTRODUCTION}

Livestock production, especially dairy cows, is one of the most important sources of methane emission. The amount of methane produced by ruminants depends mainly on diet composition. Forage, which includes high levels of crude fibre, potentially produces more methane in comparison with concentrate. It is estimated that $1 \mathrm{~kg}$ of crude fibre gives $79 \mathrm{~g}$ of methane, whereas $1 \mathrm{~kg}$ of starch about $10 \mathrm{~g} \mathrm{CH}_{4}$ (Pilarczyk, 1997).

Johnson and Johnson (1995) showed that highly digestible diets usually yield lower methane emissions than poor quality ones. Improving forage quality can improve productivity of ruminants due to increased dry matter and energy intake.

\footnotetext{
${ }^{4}$ Corresponding author: e-mail: adamck@jay.au.poznan.pl
} 
According to Hergarty (1999), the most practical means of reducing methane emission is increasing forage digestibility. There is relatively little information available in the literature on methane production from silages of different quality after improved fermentation by forage additives.

In the present study, the influence of adding a lactic acid bacterial inoculant and chemical additives (KemiSile 2000, VTT) to grass-clover silage on methane production and rumen fermentation in a batch culture system was examined.

\section{MATERIAL AND METHODS}

The present study was based on 50-kg ruminally fistulated Polish Merino ewes fed a standard concentrate-hay diet. Ruminal fluid was collected $2 \mathrm{~h}$ after feeding through an anaerobic tube into an Erlenmeyer flask. The flask was not disturbed for $30 \mathrm{~min}$ while it was incubated in a $39^{\circ} \mathrm{C}$ water bath, permitting feed particles to rise to the top. Particle-free fluid from the bottles was anaerobically transferred to an incubating medium, as described by Szumacher-Strabel et al. (2004). Particle-free fluid was mixed with medium at a $2: 3$ ratio and $40 \mathrm{ml}$ was anaerobically transferred to $125-\mathrm{ml}$ serum bottles containing: $0.4 \mathrm{~g}$ grass-clover forage without additives; $0.4 \mathrm{~g}$ grassclover forage with biological additives (VTT; Lactobacillus plantarum E-78076), or $0.4 \mathrm{~g}$ grass-clover forage with chemical additives (KemiSile 2000, composed of formic acid, ammonia formate, propionic acid and benzoic acid/ethyl benzoate). The chemical composition of the grass-clover silage is shown in Table 1.

Table 1. Chemical composition of grass-clover silage with chemical (KemiSile 2000) and biological (VTT) additives

\begin{tabular}{lrrr}
\hline Type of silage & Control & KemiSile 2000 & \multicolumn{1}{c}{ VTT } \\
\hline $\mathrm{pH}$ & 3.80 & 3.89 & 3.74 \\
Dry matter, \% & 15.67 & 16.06 & 16.73 \\
Organic matter, \% & 13.71 & 14.08 & 14.61 \\
Ammonia, \% & 0.07 & 0.19 & 0.04 \\
Volatile fatty acids, g/kg DM & & & \\
$\quad$ acetate & 30.63 & 22.73 & 21.52 \\
$\quad$ propionate & 4.47 & 12.45 & 5.38 \\
$\quad$ butyrate & 0.41 & 0.41 & 0.41 \\
$\quad$ lactic & 50.63 & 52.30 & 83.68 \\
& & & \\
ADF, g/kg DM & 291.64 & 275.84 & 278.54 \\
NDF, g/kg DM & 384.81 & 367.37 & 395.70 \\
\hline
\end{tabular}

After $24 \mathrm{~h}$ incubation gas samples were analysed for methane content by GC, liquid samples for $\mathrm{pH}$, VFA (GC, Varian, Star $3400 \mathrm{CX}$ ) and ammonia (Nessler method, at $400 \mathrm{~nm}$ ). Rumen fluid was analysed with regard to bacteria and 
protozoa counts. In vitro dry matter disappearance (IVDMD) was calculated by difference. All data was analysed using SAS procedures (User's Guide, 1996).

\section{RESULTS}

Supplementing the grass-clover silage with biological and chemical additives significantly increased $(\mathrm{P} \leq 0.05)$ in vitro dry matter disappearance (Table 2$)$ and bacteria count $(\mathrm{P} \leq 0.05)$. Silage additives usually did not affect the VFA percentage. Difference in isovalerate and acetate to propionate ratio were significant $(\mathrm{P} \leq 0.05)$. A significant increase $(\mathrm{P} \leq 0.01)$ in methane production in groups supplemented with KemiSile 2000 and VTT was found (Table 2).

Table 2. Effect of biological and chemical additives on 24-h in vitro fermentation pattern of grassclover silage in batch culture studies $(n=4)$

\begin{tabular}{lcccccc}
\hline \multirow{2}{*}{ Type of silage } & \multicolumn{2}{c}{ Control } & \multicolumn{2}{c}{ KemiSile 2000 } & \multicolumn{2}{c}{ VTT } \\
\cline { 2 - 7 } & mean & SD & mean & SD & mean & SD \\
\hline Rumen fluid properties & & & & & & \\
pH & 6.68 & 0.12 & 6.71 & 0.09 & 6.69 & 0.05 \\
ammonia, mmol/L & 18.39 & 1.92 & 18.89 & 2.63 & 17.65 & 3.15 \\
Volatile fatty acids, \% of total & & & & & & \\
acetate (A) & 59.60 & 2.33 & 60.90 & 0.58 & 61.17 & 0.33 \\
propionate (P) & 20.70 & 0.09 & 20.31 & 0.14 & 20.72 & 0.12 \\
isobutyrate & 3.42 & 0.87 & 4.41 & 0.38 & 3.95 & 0.12 \\
butyrate & 8.99 & 1.22 & 8.32 & 0.01 & 8.12 & 0.07 \\
isovalerate & $5.62^{\mathrm{a}}$ & 2.17 & $4.28^{\mathrm{b}}$ & 0.37 & $4.29^{\mathrm{b}}$ & 0.11 \\
valerate & 1.66 & 0.28 & 1.79 & 0.04 & 1.76 & 0.03 \\
A/P & $2.88^{\mathrm{b}}$ & 0.13 & $3.00^{\mathrm{a}}$ & 0.01 & $2.95^{\mathrm{a}}$ & 0.05 \\
& & & & & & \\
Rumen fluid microbial counts & & & & & & \\
bacteria, 10 $\mathrm{ml}^{-1}$ & $12.33^{\mathrm{b}}$ & 0.58 & $15.67^{\mathrm{a}}$ & 2.08 & $15.67^{\mathrm{a}}$ & 1.15 \\
protozoa, $10^{4} \mathrm{ml}^{-1}$ & 9.60 & 15.17 & 9.60 & 4.37 & 6.77 & 17.10 \\
IVDMD*, \% & $44.47^{\mathrm{b}}$ & 0.32 & $45.93^{\mathrm{a}}$ & 0.02 & $45.80^{\mathrm{a}}$ & 0.29 \\
methane, mM & $3.44^{\mathrm{C}}$ & 0.17 & $3.82^{\mathrm{B}}$ & 0.15 & $3.99^{\mathrm{A}}$ & 0.02 \\
\hline
\end{tabular}

means with the same letter are not significantly different. ${ }^{\mathrm{a}, \mathrm{b}}-\mathrm{P} \leq 0.05$; $^{\mathrm{A}, \mathrm{B}, \mathrm{C}}-\mathrm{P} \leq 0.01$

* in vitro dry matter disappearance

\section{DISCUSSION}

The use of biological and chemical additives may improve fermentation of silage and thus increase fibre degradation and silage stability. In the present study neither VTT nor KemiSile 2000 affected the VFA profile, which agrees with previous studies (Calsamiglia et al., 2002). However, the acetate:propionate ratio was significantly higher in silages with additives. This is in contrast to the results presented by Colombatto et al. (2003) who found no differences. The higher value of this parameter corresponds to an increased level of methane production in the silage with VTT or KemiSile 2000. The higher level of methane emission observed in our study can 
be explained by the increased IVDMD level and bacteria count. Forage quality is considered a factor affecting the extent of methane production by dairy cows (O'Mara, 2004). A good quality forage offered to ruminants may significantly improve milk yield as a consequence of increased DM and energy intake and, on the other hand, reduce the amount of methane per kg of produced milk (Moss et al., 2000).

\section{CONCLUSIONS}

The nutritive value of silage should be first investigated in an in vitro system, which will give some information on further animal productivity and environmental impact.

\section{REFERENCES}

Calsamiglia S., Ferret A., Devant M., 2002. Effects of $\mathrm{pH}$ and $\mathrm{pH}$ fluctuations on microbial fermentation and nutrient flow from a dual-flow continuous culture system. J. Dairy Sci. 85, 574-579

Colombatto D., Hervás G., Yang W.Z., Beauchemin K.A., 2003. Effects of enzyme supplementation of a total mixed ration on microbial fermentation in continuous culture, maintained at high and low pH. J. Anim. Sci. 81, 2617-2627

Hegarty R.S., 1999. Mechanisms for competitively reducing ruminal methanogenesis. Aust. J. Agr. Res. 50, 1299-1305

Johnson K.A., Johnson D.E., 1995. Methane emissions from cattle. J. Anim. Sci. 73, 2483-2492

Moss A. R., Jouany J. P., Newbold J., 2000. Methane production by ruminants: its contribution to global warming. Ann. Zootech. 49, 231-253

O'Mara F., 2004. Greenhouse gas production from dairying: reducing methane production. Advan. Dairy Technol. 16, 295-309

Pilarczyk A., 1997. Methane emission from livestock animals. Proceedings of Animal Nutrition Conference. Balice (Poland), pp. 9-19

SAS ${ }^{\circledR}$ 1996. SAS/STAT Users Guide (Release 6.12). SAS Institute Inc., Cary, NC

Szumacher-Strabel M., Martin S. A., Potkański A., Cieślak A., Kowalczyk J., 2004. Changes in fermentation processes as the effect of vegetable oil supplementation in in vitro studies. J. Anim. Feed Sci. 13, 215-218

\section{STRESZCZENIE}

\section{Produkcja metanu w treści żwacza $\mathrm{z}$ dodatkiem zakiszanych traw i koniczyny in vitro}

W doświadczeniu z wykorzystaniem systemu „batch culture” testowano kiszonkę trawiastokoniczynową z biologicznym (VTT) lub chemicznym (KemiSile 2000) dodatkiem. W inkubowanych próbach kiszonek określono poziom emisji metanu, podstawowe wskaźniki biochemiczne oraz liczebność bakterii i pierwotniaków. Stwierdzono statystycznie istotny wzrost $(\mathrm{P} \leq 0,05)$ strawności suchej masy oraz liczebności bakterii w kiszonkach z dodatkami. Dodatki nie miały jednak wpływu na procentową zawartość LKT. Stwierdzono statystycznie istotny wzrost $(\mathrm{P} \leq 0,05)$ poziomu kwasu izowalerianowego oraz stosunku kwasu octowego do propionowego (A/P) oraz poziomu emisji metanu $(\mathrm{P} \leq 0,01)$. 